\title{
Highly Efficient Reproducible Perovskite Solar Cells Prepared by Low-Temperature Processing
}

\author{
Hao Hu ${ }^{1}$, Ka Kan Wong ${ }^{1}$, Tom Kollek ${ }^{2}$, Fabian Hanusch ${ }^{3}$, Sebastian Polarz ${ }^{2}$, Pablo Docampo ${ }^{3}$ \\ and Lukas Schmidt-Mende ${ }^{1, *}$ \\ 1 Department of Physics, University of Konstanz, 78457 Konstanz, Germany; hao.hu@uni-konstanz.de (H.H.); \\ ka.kan.wong@uni-konstanz.de (K.K.W.) \\ 2 Department of Chemistry, University of Konstanz, 78457 Konstanz, Germany; \\ tom.kollek@uni-konstanz.de (T.K.); Sebastian.Polarz@uni-konstanz.de (S.P.) \\ 3 Department of Chemistry, University of Munich (LMU), 81377 Munich, Germany; \\ fabian.hanusch@cup.lmu.de (F.H.); pablo.docampo@cup.uni-muenchen.de (P.D.) \\ * Correspondence: Lukas.Schmidt-Mende@uni-konstanz.de; Tel.: +49-7531-88-5409 \\ Academic Editor: Derek J. McPhee \\ Received: 4 April 2016; Accepted: 21 April 2016; Published: 23 April 2016
}

\begin{abstract}
In this work, we describe the role of the different layers in perovskite solar cells to achieve reproducible, $\sim 16 \%$ efficient perovskite solar cells. We used a planar device architecture with PEDOT:PSS on the bottom, followed by the perovskite layer and an evaporated $\mathrm{C}_{60}$ layer before deposition of the top electrode. No high temperature annealing step is needed, which also allows processing on flexible plastic substrates. Only the optimization of all of these layers leads to highly efficient and reproducible results. In this work, we describe the effects of different processing conditions, especially the influence of the $\mathrm{C}_{60}$ top layer on the device performance.
\end{abstract}

Keywords: perovskite solar cells; perovskite solar cell structures

\section{Introduction}

Perovskite solar cells have attracted a lot of attention since their first report in 2009 [1]. Within five years, the reported efficiency has exceeded over 20\% [2,3], which makes it an extremely promising and fast developing candidate for a next generation solar cell. This exciting progress is attributed to the application and exploration of organic-inorganic lead-halide perovskite. Perovskite is a large class of materials, named after the Russian mineralogist Lev Perovski. This special lead-halide perovskite possesses almost all desired properties for light-harvesting solar cell materials, such as suitable direct band-gap [4-7], strong light absorption ability [8,9], long charge carrier diffusion length [10-13] and so on. It is exceptional that it forms an excellent light harvesting semiconductor material from solution processing.

Perovskite solar cells were first fabricated using dye-sensitized solar cell architecture with the perovskite as a thin absorber layer on top of a mesoporous $\mathrm{TiO}_{2}$ electron acceptor layer [14-16]. Soon, it became clear that the mesoporous $\mathrm{TiO}_{2}$ is not needed for charge separation as exciton binding energy in perovskites is very low (comparable to inorganic semiconductors) and charge diffusion lengths for electrons and hole are large and relatively balanced [12,13]. Consecutively, planar n-i-p perovskite solar cell architectures have successfully been fabricated [17-19]. However, in the two types of architecture above, the high temperature sintering process of the $\mathrm{TiO}_{2}$ film (mesoporous or planar) and serious hysteresis behavior [20-23] have become an obstacle to potential commercial application.

In contrast, an inverted perovskite $\mathrm{p}-\mathrm{i}-\mathrm{n}$ planar heterojunction can be fabricated by a low-temperature process when using poly-(2,3-dihydrothieno-1,4-dioxin)-poly(styrene -sulfonate) (PEDOT:PSS) and $\mathrm{C}_{60}$ as hole and electron extraction layers. Such cells are compatible with commercial 
roll-to-roll fabrication techniques also on flexible substrates, and the hysteresis phenomenon is also greatly suppressed in this cell layout [24-28]. Therefore, a lot of efforts have been focused on achieving the full potential of $\mathrm{p}-\mathrm{i}-\mathrm{n}$ type perovskite solar cells. Several film deposition methods have been used to fabricate perovskite films in flat p-i-n heterojunction solar cells such as two-step dipping [29] or casting [27,30], and a one-step solution processing method [25,31-33]. In the latter case, different solvent engineering treatments [34], pre or post annealing treatments [35] or additives (such as i.e., $\mathrm{H}_{2} \mathrm{O}$ [36], [6,6]-phenyl-C61-butyric acid methyl ester (PCBM) [37], hydriodic acid [26], 1,8-diiodooctane (DIO) [38] and so on) have been studied to achieve a uniform and pin-hole free perovskite film. However, despite the great progress, it still remains a difficult task to deposit compact high-quality perovskite films.

In this article, a novel vacuum assisted one-step solution (VAOS) method is reported for producing high-quality perovskite layers. After optimization, over $16 \%$ efficiency is achieved with a fill factor around $80 \%$. This method is highly reproducible with over $15 \%$ statistical average and over $16 \%$ maximum efficiency.

\section{Results}

A schematic of the device structure used for optimizing the solar cell performance is shown in Figure 1. We have prepared our devices on glass substrates with a commercial indium-tin-oxide (ITO) layer. As the first layer, we spin-coat PEDOT:PSS, which is used as a base for the perovskite layer that is spin-coated afterwards. The following layers, such as $\mathrm{C}_{60}, \mathrm{LiF}$ and $\mathrm{Ag}$ top contact are consecutively evaporated. Our measurements show that the preparation of the perovskite layer and the evaporation of the $\mathrm{C}_{60}$ layer play significant roles for the final device performance. Therefore, we will focus here in more detail on these layers. All the other layers are processed in a common way and details are described in Section 4.

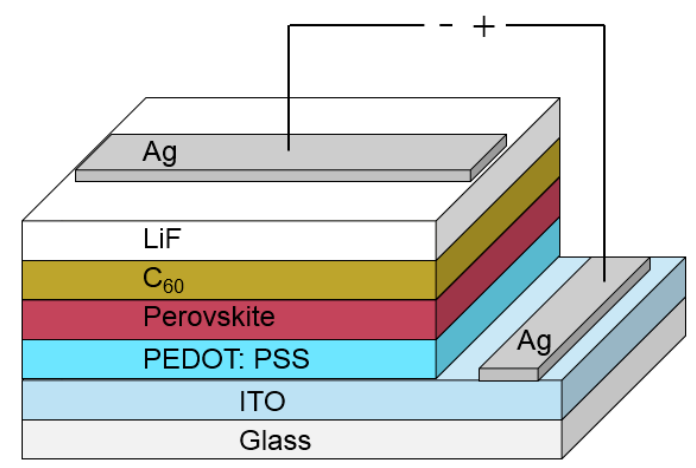

Figure 1. In this figure, a schematic of the used device structure containing all layers is presented. The layer thicknesses are not in scale. The different layer thicknesses are presented in Section 4.2 for optimized solar cell performance.

\subsection{Perovskite Layer}

The preparation of perovskite film plays a key role in the fabrication of the whole device. It has been widely accepted that the perovskite crystalization process needs to be carefully tuned to get compact films $[39,40]$. Perovskite has strong polarity and is prone to forming uncontinuous films. Different precursor solutions and additives have been reported to achieve better film morphology by speeding up [41] or slowing down $[38,42,43]$ the crystallization dynamics. Here, we fabricate a compact and pin-hole free perovskite layer by accelerating the crystallization process by the vacuum assisted one-step solution method (VAOS).

The VAOS method diagram is shown in Figure 2. Simply, mixed halide perovskite solution is spin-coated on ITO/PEDOT:PSS substrates in the glovebox with less than $5 \mathrm{ppm}$ moisture level. Then, the substrates are transferred immediately onto a hotplate in a vacuum chamber. A combination 
of higher temperature and a vacuum removes very quickly all residual solvent leading to a fast crystallization process in the film, which is expected to be faster than the commonly used temperature annealing without additional vacuum. In Figure 3, the top-view and cross-section SEM image of perovskite films are presented.

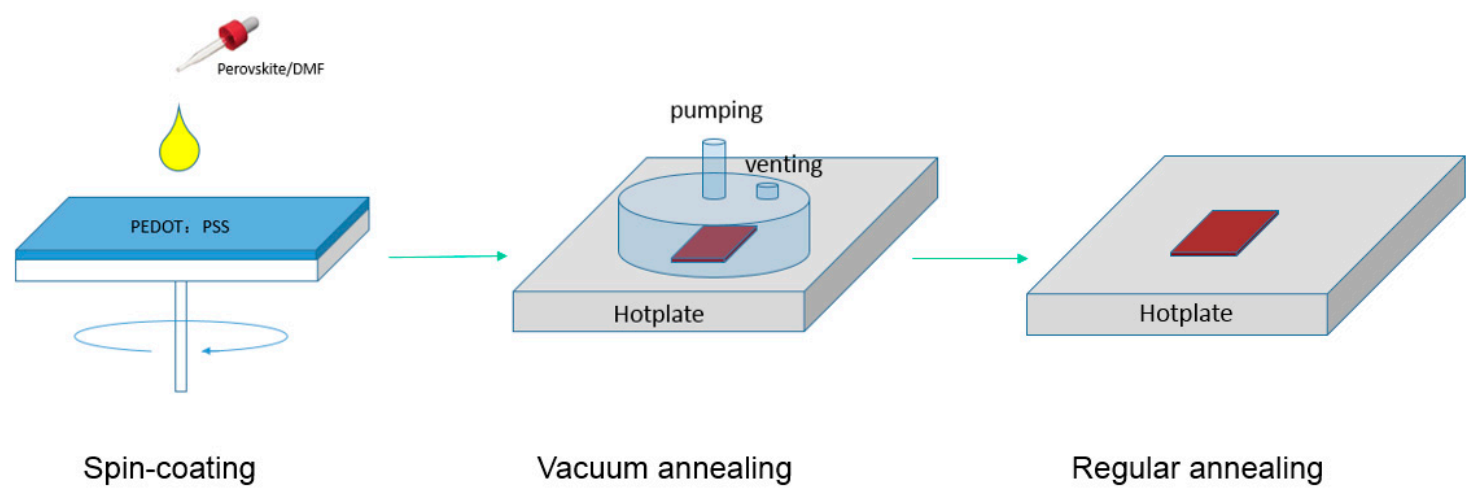

Figure 2. Schematic of the vacuum assisted one-step solution (VAOS) preparation method of the perovskite film.

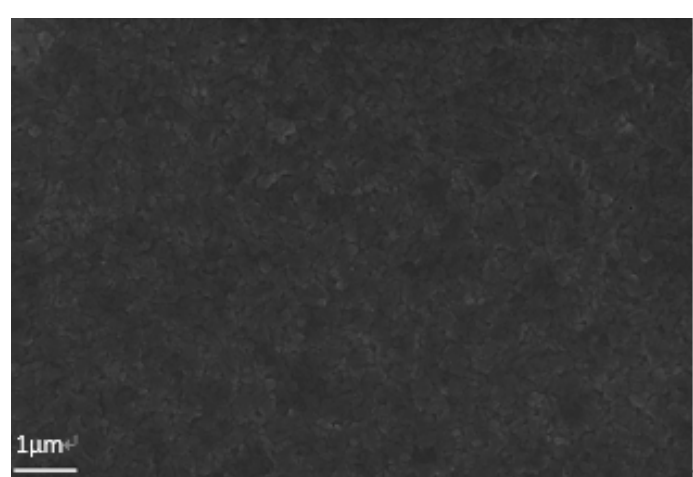

(a)

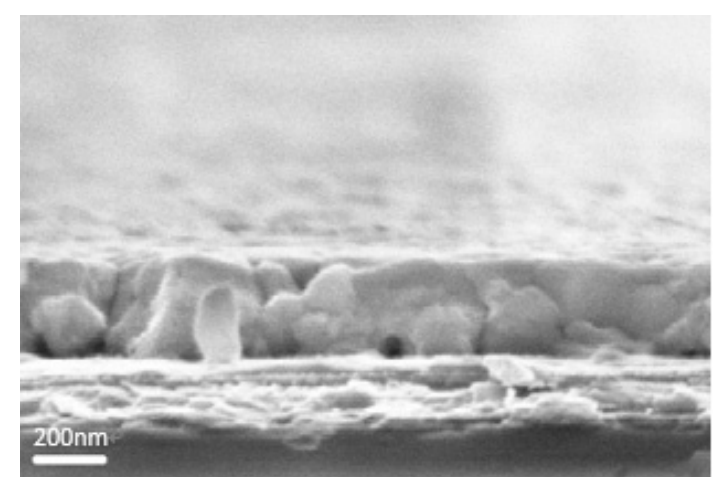

(b)

Figure 3. Smooth, uniform, pin-hole free perovskite film (a) top-view; (b) cross-section SEM images.

The film is quite compact and no pin-holes were observed on the top-view image. On the cross-section image, the perovskite layer on ITO/PEDOT:PSS has a uniform thickness of $300 \mathrm{~nm}$ as demonstrated in Figure 3b).

Compared to other methods, because of the fast crystallization process, the perovskite crystals are relatively small and have a wide range of size distribution (from around $100 \mathrm{~nm}$ to $1 \mu \mathrm{m}$ ). On the other hand, the crystallization nuclei are forced to pack closely and form a very flat and continuous, virtually pin-hole free film. It is worth mentioning that the film is so flat that no obvious undulation could be observed even for an only $70 \mathrm{~nm}$ thick perovskite thin film (see Supplementary Material Figure S1), which enables simple formation of semi-transparent perovskite solar cells by reducing the film thickness. During vacuum annealing, the perovskite film color changed from colorless to red-brown, and longer vacuum annealing leads to a notably darker color. It has been found the vacuum annealing needs to be carefully optimized regarding annealing time and temperature, as soon as fully conversion is completed, further annealing could be harmful leading to perovskite decomposition [44,45]. In our experiments, a vacuum annealing directly after spin-coating of the perovskite film for $4 \mathrm{~min}$ at $80{ }^{\circ} \mathrm{C}$ leads to the most efficient device performance. 


\section{2. $C_{60}$ Layer}

\subsubsection{Influence of $\mathrm{C}_{60}$ Layer Thickness}

$\mathrm{C}_{60}$ layer is used to act as a selective electron extraction layer in the solar cell. Its thickness needs to be carefully controlled, as it needs to be thick enough to form a compact layer over the perovskite film, but a too thick $\mathrm{C}_{60}$ layer will increase the series resistance of the device. $\mathrm{C}_{60}$ layers with different thickness have been thermally evaporated on top of the perovskite film. In Figure 4a, the influence of the $\mathrm{C}_{60}$ layer thickness on the device performance is shown. Detailed solar cell parameters are summarized in Table 1. Clearly, $20 \mathrm{~nm} \mathrm{C}_{60}$ is already enough as a hole-blocking layer, and doubling its thickness greatly impedes its ability to transfer electrons which can be observed in a low fill factor and also lower photocurrent density. If the layer is too thin, the fill factor and photocurrent density also decreases slightly, which is assumed to be due to a not full coverage of the perovskite film without any pinholes. Compared to PCBM, which is usually around $100 \mathrm{~nm}$ [30], $\mathrm{C}_{60}$ is more electron-conductive [46] and requires a very flat perovskite film as a layer underneath. Only, in this case, it is possible to have thin, but compact and pinhole-free films.

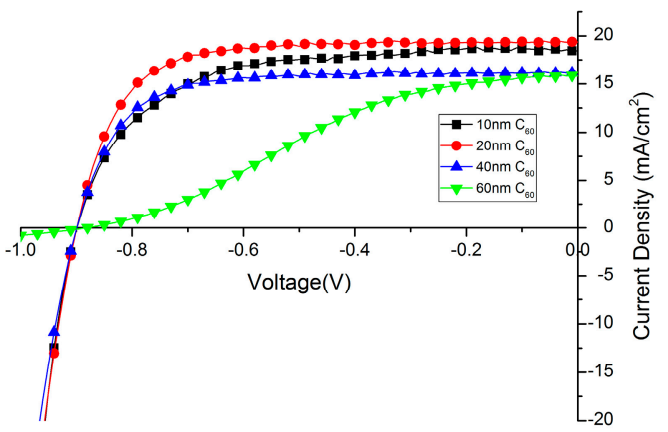

(a)

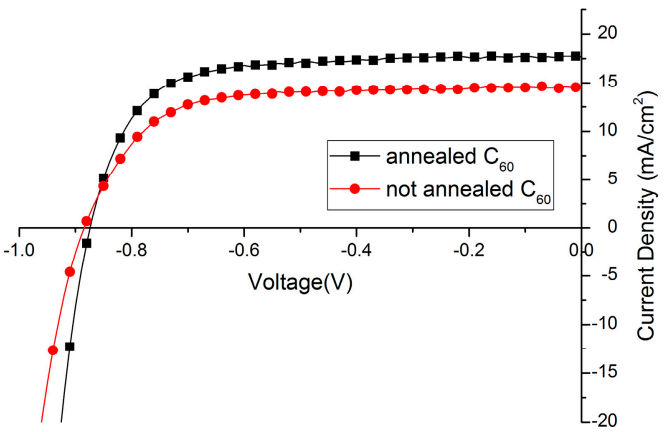

(b)

Figure 4. Influence of $\mathrm{C}_{60}$ layer (a) thickness; and (b) annealing effect on device performance.

Table 1. Effect of $\mathrm{C}_{60}$ layer thickness on device performance.

\begin{tabular}{ccccc}
\hline C $_{\mathbf{6 0}}$ Layer Thickness & PCE (\%) & FF & V $_{\text {OC }}(\mathbf{m V})$ & J SC $\left._{\text {(mA/cm }} \mathbf{~}\right)$ \\
\hline $10 \mathrm{~nm}$ & 10.5 & 63.6 & 899 & 18.4 \\
$20 \mathrm{~nm}$ & 12.2 & 72.2 & 899 & 19.4 \\
$40 \mathrm{~nm}$ & 9.3 & 65.9 & 902 & 16.1 \\
$60 \mathrm{~nm}$ & 4.8 & 35.0 & 884 & 15.8
\end{tabular}

PCE: power conversion efficiency, FF: fill factor, $\mathrm{V}_{\mathrm{OC}}$ : open circuit voltage, JSC: short circuit current density.

\subsubsection{Influence of $\mathrm{C}_{60}$ Annealing}

It is found that the performance of solar cells will benefit from a short annealing treatment after deposition of $\mathrm{C}_{60}$ layer ( $10 \mathrm{~min}$ at $90{ }^{\circ} \mathrm{C}$ in $\mathrm{N}_{2}$ atmosphere), mainly due to the increase of photocurrent. (Figure 4b, Table 2). It has been reported that PCBM strongly diffuses through films when annealed. It is expected that also the $C_{60}$ diffuses with annealing and changes the perovskite $/ C_{60}$ interface promoting charge transfer [30]. Additional aggregation might increase the charge carrier mobility of the $\mathrm{C}_{60}$ film, thus improving charge collection at the electrode. 
Table 2. Annealing effect of $\mathrm{C}_{60}$ layer.

\begin{tabular}{ccccc}
\hline Treatment & PCE (\%) & FF & V $_{\text {OC }}(\mathbf{m V})$ & J SC $_{\left(\mathbf{m A} / \mathbf{c m}^{2}\right)}$ \\
\hline Annealed $\mathrm{C}_{60}$ & 11.5 & 71.0 & 874 & 17.7 \\
Non-annealed $\mathrm{C}_{60}$ & 9.35 & 69.5 & 885 & 14.5 \\
\hline
\end{tabular}

PCE: power conversion efficiency, FF: fill factor, $\mathrm{V}_{\mathrm{OC}}$ : open circuit voltage, JSC: short circuit current density.

\subsection{Further Optimization}

Lithium fluoride $(\mathrm{LiF})$, bathocuproine $(\mathrm{BCP})$ or $\mathrm{Ca}$ are widely used as the interfacial layer between electron transport layer (ETL) and metal back contact. In this paper, the effect of LiF is studied. Amazingly, the fill factor (FF) of solar cells could be improved from $70 \%-75 \%$ to around $80 \%$ just by depositing $1 \mathrm{~nm} \mathrm{LiF}$ before Ag evaporation (Figure 5, Table 3). Such an effect has been reported [34,47,48], implying the energy mismatch between cathode and electron transporting layer is compensated by the formation of dipoles with $\mathrm{LiF}$ insertion layer. We also expect that the $\mathrm{LiF}$ layer protects the layers underneath when the silver is evaporated on top. Less silver will diffuse into the film forming high conducting channels leading to a recombination reducing fill-factor.

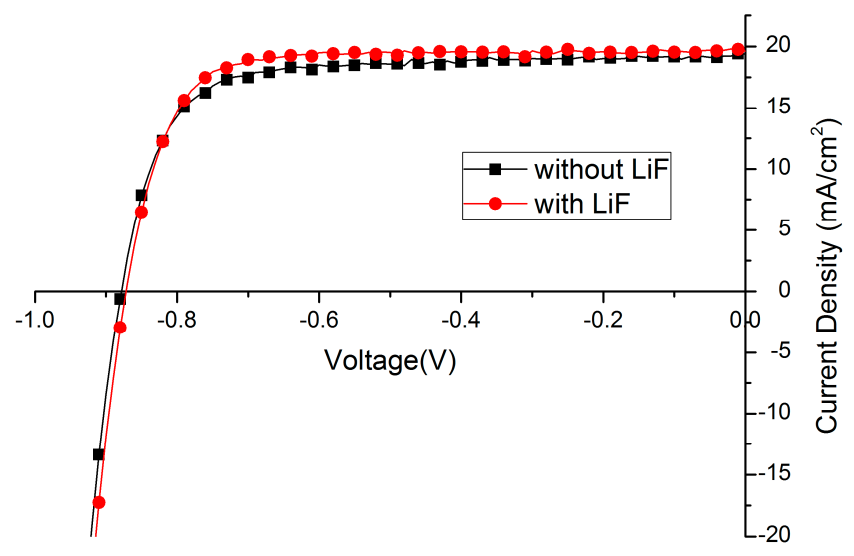

Figure 5. Effect of lithium fluoride (LiF) layer on Current density -Voltage (J-V) curve.

Table 3. Effect of lithium fluoride ( $\mathrm{LiF})$ layer on solar cell performance.

\begin{tabular}{ccccc}
\hline Device & PCE (\%) & FF & V $_{\text {OC }}(\mathbf{m V})$ & JSC $\left(\mathbf{m A} / \mathbf{c m}^{\mathbf{2}}\right)$ \\
\hline Without LiF & 12.6 & 74.4 & 878 & 19.4 \\
With LiF & 13.3 & 78.7 & 872 & 19.6 \\
\hline
\end{tabular}

PCE: power conversion efficiency, FF: fill factor, $\mathrm{V}_{\mathrm{OC}}$ : open circuit voltage, JSC: short circuit current density.

\subsection{Optimized Solar Cell Performance and Statistical Results}

Based on the optimization results mentioned above, we deposited 30 perovskite films and fabricated solar cells in successive three batches. The performance of the best fully optimized solar cell is presented in Figure 6 and Table 4 with no obvious hysteresis behavior. 


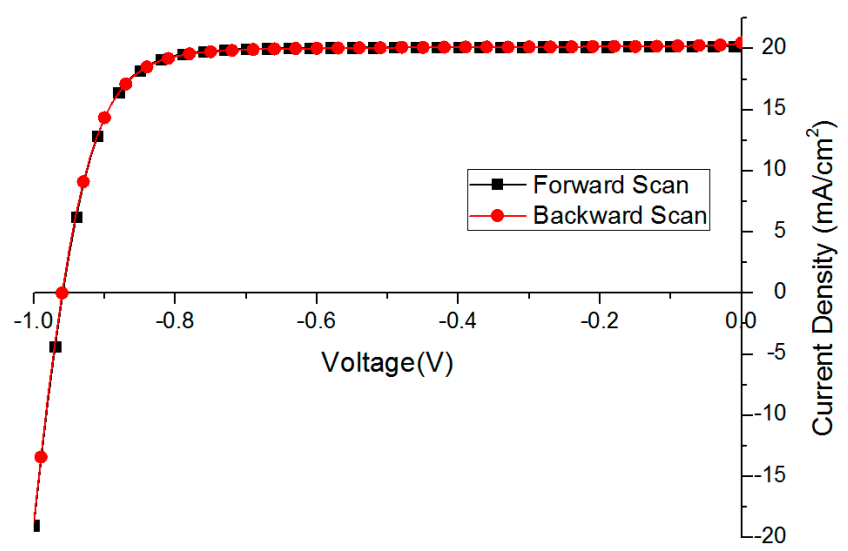

Figure 6. The best solar cell performance without hysteresis behavior (scan rate $0.1 \mathrm{~V} / \mathrm{s}$ ).

Table 4. The best perovskite solar cell performance after full optimization.

\begin{tabular}{ccccc}
\hline Scan direction & PCE $(\%)$ & FF & V $_{\text {OC }}(\mathbf{m V})$ & J $_{\text {SC }}\left(\mathbf{m A} / \mathbf{c m}^{\mathbf{2}}\right)$ \\
\hline Backward scan & 16.4 & 79.4 & 960 & 20.5 \\
Forward scan & 16.4 & 81.0 & 959 & 20.2
\end{tabular}

PCE: power conversion efficiency, FF: fill factor, $\mathrm{V}_{\mathrm{OC}}$ : open circuit voltage, JSC: short circuit current density.

The FF of the backward scan is lower (79.4 vs. 81.0 in Table 4) mainly due to a steeper current drop at 0 bias points, which is attributed to certain charge accumulation.

The statistical distribution of these results is shown in Figure 7. As can be seen, our fabrication method is quite reproducible, and over $80 \%$ solar cells have over $14 \%$ efficiency. The inefficient results are considered to come from intrinsic flaw-prone spin-coating process which, with the oversaturated precursor solution, sometimes induces macroscopic pinholes.

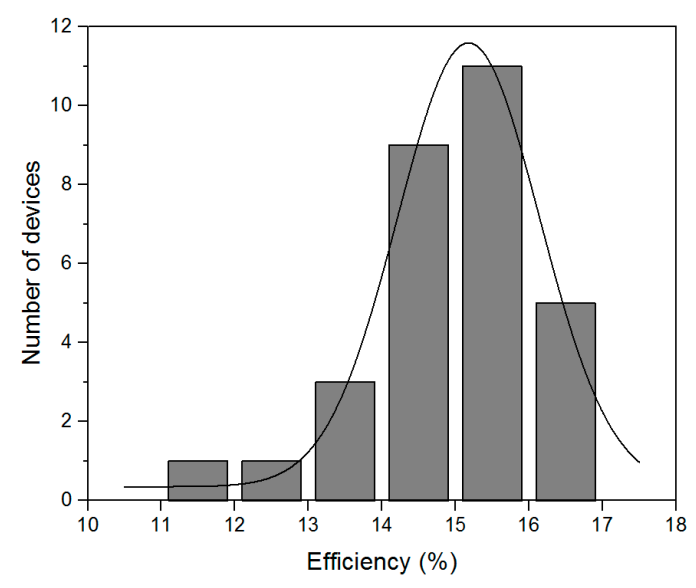

Figure 7. The statistical distribution of 30 solar cell efficiencies fabricated in three successive processes.

\section{Discussion}

The optimization results in the previous sections clearly indicate that not only does the perovskite layer preparation play a significant role in the final device performance, but also the interfacial layers. With the described method, we could achieve a champion device efficiency over $16 \%$. Most cells showed a performance exceeding $14 \%$ efficiency.

It has been considered that large perovskite crystals are superior to small ones in solar cells, as they have less grain boundaries, thus less recombination and longer charge carrier life time. However, in 
our case, we show that, even with small perovskite crystals, solar cells still work very efficiently with an over $80 \%$ fill factor with optimized $\mathrm{C}_{60}$ and $\mathrm{LiF}$ layer. The presented novel VAOS deposition method could produce ultra-thin, ultra-flat and compact perovskite film, and we believe it will contribute to this flourishing research area.

\section{Materials and Methods}

\subsection{Preparation of the Precursor}

Methylammonium iodide (MAI) was synthesized as reported [49]. In short, 24 mL of methylamine solution (33\% in ethanol, Sigma-Aldrich, Schnelldorf, Germany) was diluted with $100 \mathrm{~mL}$ of absolute ethanol in a $250 \mathrm{~mL}$ round-bottom flask. In addition, $10 \mathrm{~mL}$ of hydroiodic acid (33 wt $\%$ ) was added under constant stirring into the flask. After reacting one hour at room temperature, the solvents were removed by rotary evaporation. The obtained white solid was washed with dry diethyl ether and finally recrystallized with ethanol. To prepare mixed-halide perovskite precursor solutions, $\mathrm{PbI}_{2}$, $\mathrm{PbCl}_{2}$ and MAI were mixed in anhydrous dimethylformamide (DMF) (99.9\%) with a molar ration of 1:1:4 [50]. The solution concentration is around $40 \mathrm{wt} \%$. The solutions were stirred at room temperature overnight in a glovebox and stored there for use.

\subsection{Fabrication of the Devices}

The ITO-coated glass substrates (15 $\Omega$ per sq) were ultrasonic cleaned for 5 min by detergent, acetone and isopropanol successively. Then, they were treated with oxygen plasma for $7 \mathrm{~min}$. After that, around $30 \mathrm{~nm}$ PEDOT:PSS (Clevios ${ }^{\mathrm{TM}}$ VP AI 4083) film was spin-coated on top (Supplementary Material Figure S2) and then annealed at $180{ }^{\circ} \mathrm{C}$ for $5 \mathrm{~min}$. Then, the substrates were transferred to a glovebox with moisture and oxygen level both lower than $5 \mathrm{ppm}$. The prepared precursor solution was spin-coated on the substrates with $3000 \mathrm{rpm}$ for $20 \mathrm{~s}$. Then, the films were transferred immediately to a vacuum chamber on a hotplate at $90^{\circ} \mathrm{C}$. After evacuating, the films turned red-brown and then were further annealed at normal pressure at $100{ }^{\circ} \mathrm{C}$ for full conversion to perovskite. Finally, a $\mathrm{C}_{60}$ layer, $\mathrm{LiF}$ layer and $\mathrm{Ag}$ back contact were thermally evaporated consecutively on top of the spin-coated perovskite film. Layer thickness details are summarized in Table 5.

Table 5. Layer deposition technique and thickness of different layers in the optimized solar cell geometry.

\begin{tabular}{ccc}
\hline Layer & Deposition Method & Thickness \\
\hline Glass & - & $1.1 \mathrm{~mm}$ \\
ITO & - & around $150 \mathrm{~nm}$ \\
PEDOT:PSS & Spin-coated & $30 \mathrm{~nm}$ \\
Perovskite & Spin-coated & $300 \mathrm{~nm}$ \\
C $_{60}$ & Evaporated & $20 \mathrm{~nm}$ \\
LiF & Evaporated & $1 \mathrm{~nm}$ \\
Ag & evaporated & $100 \mathrm{~nm}$ \\
\hline
\end{tabular}

\subsection{Device Characterization}

The morphology of the perovskite film were characterized using a scanning electron microscopy (SEM) (Zeiss Neon 40 EsB, Oberkochen, Germany) operated at $5 \mathrm{kV}$ accelerating voltage. Current density-voltage $(\mathrm{J}-\mathrm{V})$ measurements were performed using a Keithley 2400 SourceMeter (Tektronix $\mathrm{GmbH}$, Keithley Instruments, Germering, Germany) controlled through a self-written LabView program (National Instruments, Austin, Texas, US). Cells were illuminated via a LOT-Oriel LS0106 solar simulator (LOT, Darmstadt, Germany) through a shadow mask with a resulting active area of $0.09 \mathrm{~cm}^{2}$. Light intensities were calibrated with a certified Si reference solar cell (Fraunhofer 
Institute, Freiburg, Germany) with a KG5 filter (Schott, Mainz, Germany). The light intensity of the solar simulator was around 0.95 sun.

Supplementary Materials: The following are available online at: http:/ /www.mdpi.com/1420-3049/21/4/542/s1, Figure S1: Ultraflat perovskite film with around $70 \mathrm{~nm}$ thickness deposited with the VAOS method, Figure S2: Cross-section SEM graph of PEDOT:PSS film.

Acknowledgments: We acknowledge funding The Federal Ministry of Education and Research (BMBF) (MesoPIN project) and the Baden-Württemberg Foundation (BioMats-SuperSol project). H.H. thanks the Chinese Scholarship Council (CSC) and K.K.W. the German Academic Exchange Service (DAAD) for funding.

Author Contributions: H.H. and K.K.W. conceived and designed the experiments. Experiments were conducted by H.H. T.K., F.H., S.P. and P.D. contributed to precursor synthesis and perovskite film preparation. L.S.-M. supervised the project. H.H. and L.S.-M. wrote the manuscript. All authors contributed to the discussion of the results.

Conflicts of Interest: The authors declare no conflict of interest.

\section{References}

1. Kojima, A.; Teshima, K.; Shirai, Y.; Miyasaka, T. Organometal Halide Perovskites as Visible-Light Sensitizers for Photovoltaic Cells. J. Am. Chem. Soc. 2009, 131, 6050-6051. [CrossRef] [PubMed]

2. Yang, W.S.; Noh, J.H.; Jeon, N.J.; Kim, Y.C.; Ryu, S.; Seo, J.; Seok, S.I. High-performance photovoltaic perovskite layers fabricated through intramolecular exchange. Science 2015, 348, 1234-1237. [CrossRef] [PubMed]

3. Jeon, N.J.; Noh, J.H.; Yang, W.S.; Kim, Y.C.; Ryu, S.; Seo, J.; Seok, S.I. Compositional engineering of perovskite materials for high-performance solar cells. Nature 2015, 517, 476-480. [CrossRef] [PubMed]

4. Walsh, A. Principles of Chemical Bonding and Band Gap Engineering in Hybrid Organic-Inorganic Halide Perovskites. J. Phys. Chem. C 2015, 119, 5755-5760. [CrossRef] [PubMed]

5. Noh, J.H.; Im, S.H.; Heo, J.H.; Mandal, T.N.; Seok, S.I. Chemical Management for Colorful, Efficient, and Stable Inorganic-Organic Hybrid Nanostructured Solar Cells. Nano Lett. 2013, 13, 1764-1769. [CrossRef] [PubMed]

6. Kulkarni, S.A.; Baikie, T.; Boix, P.P.; Yantara, N.; Mathews, N.; Mhaisalkar, S. Band-gap tuning of lead halide perovskites using a sequential deposition process. J. Mater. Chem. A 2014, 2, 9221-9225. [CrossRef]

7. D'Innocenzo, V.; Srimath Kandada, A.R.; De Bastiani, M.; Gandini, M.; Petrozza, A. Tuning the Light Emission Properties by Band Gap Engineering in Hybrid Lead Halide Perovskite. J. Am. Chem. Soc. 2014, 136, 17730-17733. [CrossRef] [PubMed]

8. De Wolf, S.; Holovsky, J.; Moon, S.-J.; Löper, P.; Niesen, B.; Ledinsky, M.; Haug, F.-J.; Yum, J.-H.; Ballif, C. Organometallic Halide Perovskites: Sharp Optical Absorption Edge and its Relation to Photovoltaic Performance. J. Phys. Chem. Lett. 2014, 5, 1035-1039. [CrossRef] [PubMed]

9. Zhu, X.; Su, H.; Marcus, R.A.; Michel-Beyerle, M.E. Computed and Experimental Absorption Spectra of the Perovskite $\mathrm{CH}_{3} \mathrm{NH}_{3} \mathrm{PbI}_{3}$. J. Phys. Chem. Lett. 2014, 5, 3061-3065. [CrossRef] [PubMed]

10. Dong, Q.; Fang, Y.; Shao, Y.; Mulligan, P.; Qiu, J.; Cao, L.; Huang, J. Electron-hole diffusion lengths $>175 \mu \mathrm{m}$ in solution-grown $\mathrm{CH}_{3} \mathrm{NH}_{3} \mathrm{PbI}_{3}$ single crystals. Science 2015, 347, 967-970. [CrossRef] [PubMed]

11. Shi, D.; Adinolfi, V.; Comin, R.; Yuan, M.; Alarousu, E.; Buin, A.; Chen, Y.; Hoogland, S.; Rothenberger, A.; Katsiev, K.; et al. Low trap-state density and long carrier diffusion in organolead trihalide perovskite single crystals. Science 2015, 347, 519-522. [CrossRef] [PubMed]

12. Stranks, S.D.; Eperon, G.E.; Grancini, G.; Menelaou, C.; Alcocer, M.J.P.; Leijtens, T.; Herz, L.M.; Petrozza, A.; Snaith, H.J. Electron-Hole Diffusion Lengths Exceeding 1 Micrometer in an Organometal Trihalide Perovskite Absorber. Science 2013, 342, 341-344. [CrossRef] [PubMed]

13. Xing, G.; Mathews, N.; Sun, S.; Lim, S.S.; Lam, Y.M.; Gratzel, M.; Mhaisalkar, S.; Sum, T.C. Long-Range Balanced Electron- and Hole-Transport Lengths in Organic-Inorganic $\mathrm{CH}_{3} \mathrm{NH}_{3} \mathrm{PbI}_{3}$. Science 2013, 342, 344-347. [CrossRef] [PubMed]

14. Im, J.H.; Lee, C.R.; Lee, J.W.; Park, S.W.; Park, N.G. 6.5\% efficient perovskite quantum-dot-sensitized solar cell. Nanoscale 2011, 3, 4088-4093. [CrossRef] [PubMed] 
15. Etgar, L.; Gao, P.; Xue, Z.S.; Peng, Q.; Chandiran, A.K.; Liu, B.; Nazeeruddin, M.K.; Gratzel, M. Mesoscopic $\mathrm{CH}_{3} \mathrm{NH}_{3} \mathrm{PbI}_{3} / \mathrm{TiO}_{2}$ Heterojunction Solar Cells. J. Am. Chem. Soc. 2012, 134, 17396-17399. [CrossRef] [PubMed]

16. Kim, H.S.; Lee, C.R.; Im, J.H.; Lee, K.B.; Moehl, T.; Marchioro, A.; Moon, S.J.; Humphry-Baker, R.; Yum, J.H.; Moser, J.E.; et al. Lead Iodide Perovskite Sensitized All-Solid-State Submicron Thin Film Mesoscopic Solar Cell with Efficiency Exceeding 9\%. Sci. Rep. 2012, 2, 591. [CrossRef] [PubMed]

17. Zhou, H.; Chen, Q.; Li, G.; Luo, S.; Song, T.-B.; Duan, H.-S.; Hong, Z.; You, J.; Liu, Y.; Yang, Y. Interface engineering of highly efficient perovskite solar cells. Science 2014, 345, 542-546. [CrossRef] [PubMed]

18. Chen, Q.; Zhou, H.; Hong, Z.; Luo, S.; Duan, H.-S.; Wang, H.-H.; Liu, Y.; Li, G.; Yang, Y. Planar heterojunction perovskite solar cells via vapor assisted solution process. J. Am. Chem. Soc. 2013, 136, 622-625. [CrossRef] [PubMed]

19. Liu, M.; Johnston, M.B.; Snaith, H.J. Efficient planar heterojunction perovskite solar cells by vapour deposition. Nature 2013, 501, 395-398. [CrossRef] [PubMed]

20. Kim, H.-S.; Park, N.-G. Parameters Affecting I-V Hysteresis of $\mathrm{CH}_{3} \mathrm{NH}_{3} \mathrm{PbI}_{3}$ Perovskite Solar Cells: Effects of Perovskite Crystal Size and Mesoporous $\mathrm{TiO}_{2}$ Layer. J. Phys. Chem. Lett. 2014, 5, 2927-2934. [CrossRef] [PubMed]

21. Shao, Y.H.; Xiao, Z.G.; Bi, C.; Yuan, Y.B.; Huang, J.S. Origin and elimination of photocurrent hysteresis by fullerene passivation in $\mathrm{CH}_{3} \mathrm{NH}_{3} \mathrm{PbI}_{3}$ planar heterojunction solar cells. Nat. Commun. 2014, 5, 5784 . [CrossRef] [PubMed]

22. Heo, J.H.; You, M.S.; Chang, M.H.; Yin, W.; Ahn, T.K.; Lee, S.-J.; Sung, S.-J.; Kim, D.H.; Im, S.H. Hysteresis-less mesoscopic $\mathrm{CH}_{3} \mathrm{NH}_{3} \mathrm{PbI}_{3}$ perovskite hybrid solar cells by introduction of Li-treated $\mathrm{TiO}_{2}$ electrode. Nano Energy 2015, 15, 530-539. [CrossRef]

23. Jena, A.K.; Chen, H.-W.; Kogo, A.; Sanehira, Y.; Ikegami, M.; Miyasaka, T. The Interface between FTO and the $\mathrm{TiO}_{2}$ Compact Layer Can Be One of the Origins to Hysteresis in Planar Heterojunction Perovskite Solar Cells. ACS Appl. Mater. Interfaces 2015, 7, 9817-9823. [CrossRef] [PubMed]

24. Docampo, P.; Ball, J.M.; Darwich, M.; Eperon, G.E.; Snaith, H.J. Efficient organometal trihalide perovskite planar-heterojunction solar cells on flexible polymer substrates. Nat. Commun. 2013, 4, 2761. [CrossRef] [PubMed]

25. Forgacs, D.; Sessolo, M.; Bolink, H.J. Lead acetate precursor based p-i-n perovskite solar cells with enhanced reproducibility and low hysteresis. J. Mater. Chem. A 2015, 3, 14121-14125. [CrossRef]

26. Heo, J.H.; Han, H.J.; Kim, D.; Ahn, T.K.; Im, S.H. Hysteresis-less inverted $\mathrm{CH}_{3} \mathrm{NH}_{3} \mathrm{PbI}_{3}$ planar perovskite hybrid solar cells with $18.1 \%$ power conversion efficiency. Energy Environ. Sci. 2015, 8, 1602-1608. [CrossRef]

27. Wu, C.-G.; Chiang, C.-H.; Tseng, Z.-L.; Nazeeruddin, M.K.; Hagfeldt, A.; Gratzel, M. High efficiency stable inverted perovskite solar cells without current hysteresis. Energy Environ. Sci. 2015, 8, 2725-2733. [CrossRef]

28. Heo, J.H.; Im, S.H. Highly reproducible, efficient hysteresis-less $\mathrm{CH}_{3} \mathrm{NH}_{3} \mathrm{PbI}_{3-\mathrm{x}} \mathrm{Cl}_{\mathrm{x}}$ planar hybrid solar cells without requiring heat-treatment. Nanoscale 2016, 8, 2554-2560. [CrossRef] [PubMed]

29. El-Henawey, M.I.; Gebhardt, R.S.; El-Tonsy, M.M.; Chaudhary, S. Organic solvent vapor treatment of lead iodide layers in the two-step sequential deposition of $\mathrm{CH}_{3} \mathrm{NH}_{3} \mathrm{PbI}_{3}$-based perovskite solar cells. J. Mater. Chem. A 2016, 4, 1947-1952. [CrossRef]

30. Chiang, C.-H.; Tseng, Z.-L.; Wu, C.-G. Planar heterojunction perovskite/PC71BM solar cells with enhanced open-circuit voltage via a (2/1)-step spin-coating process. J. Mater. Chem. A 2014, 2, 15897-15903. [CrossRef]

31. Chiang, Y.-F.; Jeng, J.-Y.; Lee, M.-H.; Peng, S.-R.; Chen, P.; Guo, T.-F.; Wen, T.-C.; Hsu, Y.-J.; Hsu, C.-M. High voltage and efficient bilayer heterojunction solar cells based on an organic-inorganic hybrid perovskite absorber with a low-cost flexible substrate. Phys. Chem. Chem. Phys. 2014, 16, 6033-6040. [CrossRef] [PubMed]

32. Jeng, J.Y.; Chen, K.C.; Chiang, T.Y.; Lin, P.Y.; Tsai, T.D.; Chang, Y.C.; Guo, T.F.; Chen, P.; Wen, T.C.; Hsu, Y.J. Nickel oxide electrode interlayer in $\mathrm{CH}_{3} \mathrm{NH}_{3} \mathrm{PbI}_{3}$ perovskite/ $\mathrm{PCBM}$ planar-heterojunction hybrid solar cells. Adv. Mater. 2014, 26, 4107-4113. [CrossRef] [PubMed]

33. Jeng, J.Y.; Chiang, Y.F.; Lee, M.H.; Peng, S.R.; Guo, T.F.; Chen, P.; Wen, T.C. $\mathrm{CH}_{3} \mathrm{NH}_{3} \mathrm{PbI}_{3}$ Perovskite/Fullerene Planar-Heterojunction Hybrid Solar Cells. Adv. Mater. 2013, 25, 3727-3732. [CrossRef] [PubMed]

34. Seo, J.; Park, S.; Chan Kim, Y.; Jeon, N.J.; Noh, J.H.; Yoon, S.C.; Seok, S.I. Benefits of very thin PCBM and LiF layers for solution-processed p-i-n perovskite solar cells. Energy Environ. Sci. 2014, 7, 2642-2646. [CrossRef] 
35. Even, J.; Pedesseau, L.; Katan, C.; Kepenekian, M.; Lauret, J.-S.; Sapori, D.; Deleporte, E. A Solid State Physics Perspective on Hybrid Perovskite Semiconductors. J. Phys. Chem. C 2015, 119, 10161-10177. [CrossRef]

36. Gong, X.; Li, M.; Shi, X.-B.; Ma, H.; Wang, Z.-K.; Liao, L.-S. Controllable Perovskite Crystallization by Water Additive for High-Performance Solar Cells. Adv. Funct. Mater. 2015, 25, 6671-6678. [CrossRef]

37. Chiang, C.-H.; Wu, C.-G. Bulk heterojunction perovskite-PCBM solar cells with high fill factor. Nat. Photon 2016, 10, 196-200. [CrossRef]

38. Liang, P.W.; Liao, C.Y.; Chueh, C.C.; Zuo, F.; Williams, S.T.; Xin, X.K.; Lin, J.; Jen, A.K. Additive enhanced crystallization of solution-processed perovskite for highly efficient planar-heterojunction solar cells. Adv. Mater. 2014, 26, 3748-3754. [CrossRef] [PubMed]

39. Moore, D.T.; Sai, H.; Tan, K.W.; Smilgies, D.M.; Zhang, W.; Snaith, H.J.; Wiesner, U.; Estroff, L.A. Crystallization kinetics of organic-inorganic trihalide perovskites and the role of the lead anion in crystal growth. J. Am. Chem. Soc. 2015, 137, 2350-2358. [CrossRef] [PubMed]

40. Tidhar, Y.; Edri, E.; Weissman, H.; Zohar, D.; Hodes, G.; Cahen, D.; Rybtchinski, B.; Kirmayer, S. Crystallization of Methyl Ammonium Lead Halide Perovskites: Implications for Photovoltaic Applications. J. Am. Chem. Soc. 2014, 136, 13249-13256. [CrossRef] [PubMed]

41. Zhang, W.; Saliba, M.; Moore, D.T.; Pathak, S.K.; Horantner, M.T.; Stergiopoulos, T.; Stranks, S.D.; Eperon, G.E.; Alexander-Webber, J.A.; Abate, A.; et al. Ultrasmooth organic-inorganic perovskite thin-film formation and crystallization for efficient planar heterojunction solar cells. Nat. Commun. 2015, 6, 6142. [CrossRef] [PubMed]

42. Chang, C.-Y.; Chu, C.-Y.; Huang, Y.-C.; Huang, C.-W.; Chang, S.-Y.; Chen, C.-A.; Chao, C.-Y.; Su, W.-F. Tuning Perovskite Morphology by Polymer Additive for High Efficiency Solar Cell. ACS Appl. Mater. Interfaces 2015, 7, 4955-4961. [CrossRef] [PubMed]

43. Heo, J.H.; Song, D.H.; Im, S.H. Planar $\mathrm{CH}_{3} \mathrm{NH}_{3} \mathrm{PbBr}_{3}$ hybrid solar cells with $10.4 \%$ power conversion efficiency, fabricated by controlled crystallization in the spin-coating process. Adv. Mater. 2014, 26, 8179-8183. [CrossRef] [PubMed]

44. Schoonman, J. Organic-inorganic lead halide perovskite solar cell materials: A possible stability problem. Chem. Phys. Lett. 2015, 619, 193-195. [CrossRef]

45. Conings, B.; Drijkoningen, J.; Gauquelin, N.; Babayigit, A.; D’Haen, J.; D'Olieslaeger, L.; Ethirajan, A.; Verbeeck, J.; Manca, J.; Mosconi, E.; et al. Intrinsic Thermal Instability of Methylammonium Lead Trihalide Perovskite. Adv. Energy Mater. 2015, 5, 1500477-1500485. [CrossRef]

46. Liang, P.W.; Chueh, C.C.; Williams, S.T.; Jen, A.K.Y. Roles of Fullerene-Based Interlayers in Enhancing the Performance of Organometal Perovskite Thin-Film Solar Cells. Adv. Energy Mater. 2015, 5, 1402321-1402327. [CrossRef]

47. Sun, K.; Chang, J.; Isikgor, F.H.; Li, P.; Ouyang, J. Efficiency enhancement of planar perovskite solar cells by adding zwitterion/LiF double interlayers for electron collection. Nanoscale 2015, 7, 896-900. [CrossRef] [PubMed]

48. Liu, X.; Yu, H.; Yan, L.; Dong, Q.; Wan, Q.; Zhou, Y.; Song, B.; Li, Y. Triple cathode buffer layers composed of PCBM, $\mathrm{C}_{60}$, and LiF for high-performance planar perovskite solar cells. ACS Appl. Mater. Interfaces 2015, 7, 6230-6237. [CrossRef] [PubMed]

49. Binek, A.; Hanusch, F.C.; Docampo, P.; Bein, T. Stabilization of the Trigonal High-Temperature Phase of Formamidinium Lead Iodide. J. Phys. Chem. Lett. 2015, 6, 1249-1253. [CrossRef] [PubMed]

50. Wang, D.; Liu, Z.; Zhou, Z.; Zhu, H.; Zhou, Y.; Huang, C.; Wang, Z.; Xu, H.; Jin, Y.; Fan, B.; et al. Reproducible One-Step Fabrication of Compact MAPbI3-xClxThin Films Derived from Mixed-Lead-Halide Precursors. Chem. Mat. 2014, 26, 7145-7150. [CrossRef]

Sample Availability: Not available.

(C) 2016 by the authors; licensee MDPI, Basel, Switzerland. This article is an open access article distributed under the terms and conditions of the Creative Commons Attribution (CC-BY) license (http://creativecommons.org/licenses/by/4.0/). 